\title{
PENGETAHUAN METAKOGNITIF UNTUK PENDIDIK DAN PESERTA DIDIK
}

\author{
Endang Indarini, Tri Sadono, dan Maria Evangeli Onate \\ Mahasiswa Magister Manajemen Pendidikan \\ FKIP Universitas Kristen Satya Wacana
}

\begin{abstract}
ABSTRAK
Tulisan ini akan menghadirkan pemaparan singkat mengenai pengetahuan metakognitif yang merupakan dimensi terpenting dari Revisi Taksonomi Bloom. Pengetahuan Metakognitif sekiranya perlu menjadi perhatian penting di dalam mewujudkan pendidikan yang berkualitas di Indonesia yang sebenarnya mampu diterapkan di dalam Kurikulum 2013. Hal itu bisa dilihat dari tujuan kurikulum 2013 yaitu untuk mendorong peserta didik atau siswa, mampu lebih baik dalam melakukan observasi, bertanya, bernalar, dan mengkomunikasikan (mempresentasikan), apa yang mereka peroleh atau mereka ketahui setelah menerima materi pembelajaran. Oleh karena itu, menjadi penting apabila para pendidik dan peserta didik mempunyai pengetahuan metakognitif dalam dirinya. Pengetahuan metakognitif merupakan salah satu dimensi pengetahuan dari Taksonomi Revisi. Pengetahuan metakognitif meliputi pengetahuan tentang strategi umum yang dapat digunakan untuk tugas yang berbeda, pengetahuan tentang kondisi di mana strategi ini dapat digunakan, pengetahuan tentang sejauh mana strategi yang efektif, dan pengetahuan tentang diri. Pengetahuan Metakognitif terdiri dari pengetahuan akan strategi belajar, Pengetahuan tentang tugas-tugas kognitif dan pengetahuan diri.
\end{abstract}

Kata kunci: Taksonomi Bloom, Pengetahuan Metakognitif, Pesertadidik

\section{PENDAHULUAN}

Masalah dan tantangan pendidikan merupakan bagian tidak terpisahkan dari pendidikan nasional. Dalam konteks dunia yang mengglobal dengan adanya era globalisasi, maka menuntut negara Indonesia bisa menyesuaikan segala kebijakan makro maupun kebijakan pendidikan yang bisa menjaga keutuhan dan kesinambungan pembangunan nasional, Fattah (2012). Masalah pendidikan dapat diatasi oleh pemerintah dengan melahirkan kebijakan-kebijakan baru dan program-program baru yang diharapkan bisa mengurangi masalah secara bertahap. Indonesia sudah berjuang untuk membantu mewujudkan hal tersebut yang terbukti dengan adanya pergantian kurikulum tujuh kali sejak tahun 1968 hingga 2013.

Sindhunata (2001) dalam pengantar bukunya yang berjudul "Pendidikan: Kegelisahan Sepanjang Hidup" mengungkapkan bahwa pendidikan seharusnya lebih daripada sekedar menghasilkan "kegunaan", pendidikan harus membantu manusia-manusia muda agar mereka dapat mengolah bakat dan kemampuan personalnya untuk menemukan kepribadiannya. Pendidikan yang membantu manusia-manusia muda, dalam tulisan ini kami sebut sebagai siswa di sekolah yang saat ini sedang ditimpa banyak persoalan. Para pendidik termasuk guru di Indonesia sedang berjuang keras memperjuangkan tugas pendidikan supaya bisa membantu para siswanya mendapatkan pendidikan yang berkualitas.

Sering kita mendengar bahwa tugas pendidikan yang paling penting adalah mengajar siswa bagaimana belajar sepanjang hidupnya menurut jalannya sendiri. Tetapi bagaimana siswa belajar "bagaimana belajar"? bagaimana siswa mengetahui apa yang telah kita pelajari dan bagaimana siswa mengarahkan belajarnya di masa datang? (Hammond, Austin, Cheung dan Martin, 2003). Semua itu adalah pertanyaan-pertanyaan 
yang diajukan oleh konsep metakognitif. Holt (2012) mengemukakan para guru saat ini miskin ide tentang apa yang mereka ajarkan, bagaimana mereka mengajar, serta mengujinya

Pengetahuan Metakognitif sering diabaikan padahal sangat diperlukan dalam mencapai tujuan pendidikan. Pengetahuan metakognitif tidak mudah didapatkan tetapi perlu pemahaman penuh mengenai apa itu metakognitif dan bagaimana pengetahuan metakognitif bisa dimiliki oleh setiap siswa.

Menteri Pendidikan dan Kebudayaan juga menambahkan bahwa perubahan kurikulum ini bertujuan untuk menelurkan generasi yang cerdas komprehensif. Tidak hanya unggul secara pengetahuan, namun generasi ini juga memiliki kepedulian pada sesama, jujur serta kreatif dan produktif.

\section{PENGETAHUAN METAKOGNITIF}

Metacognition berasal dari dua kata yang dirangkai yaitu meta dan kognisi (cognition). Meta berasal (Yunani) $\varepsilon \tau \dot{\alpha}$, bahasa Inggris: after, beyond, with, adjacent), adalah suatu prefik yang digunakan dalam bahasa Inggris untuk menunjukkan pada suatu abstraksi dari suatu konsep. Menurut Flavel (Jonassen, 2000) metakognitif yaitu kesadaran seseorang tentang bagaimana ia belajar, kemampuan untuk menilai kesukaran sesuatu masalah, kemampuan untuk mengamati tingkat pemahaman dirinya, kemampuan menggunakan berbagai informasi untuk mencapai tujuan, dan kemampuan menilai kemajuan belajar sendiri. Kegiatan-kegiatan Metakognitif meminta siswa untuk merefleksikan apa yang mereka ketahui, apa yang mereka pedulikan dan apa yang mereka bisa lakukan tidak hanya menolong siswa membangun kesadaran dirinya, melainkan juga memberi informasi yang bernilai bagi guru (Hammond, Austin, Cheung dan Martin, 2003). Maka penting bagi para guru untuk memberi kesempatan sesering mungkin kepada siswanya untuk merefleksikan belajarnya agar mereka mengetahui apa yang mereka lakukan baik ketika mereka berhasil maupun ketika mereka gagal dalam belajar.
Flavell tahun 1979 dalam artikel klasiknya mengenai metakognisi, mengungkapkan bahwa metakognisi mencakup tiga macam pengetahuan, yaitu pengetahuan tentang strategi, pengetahuan tentang tugas kognitif, dan pengetahuan diri. Pintrich (2002) menyajikan kembali kerangka kerja umum mengenai metakognisi ke dalam tiga kategori dengan memasukkan pengetahuan siswa tentang strategi umum untuk belajar dan berpikir (pengetahuan tentang strategi) dan pengetahuan mereka untuk tugas-tugas kognitif serta kapan dan mengapa menggunakan strategi yang berbeda (pengetahuan tentang tugas-tugas kognitif, termasuk pengetahuan kontekstual dan kondisional yang tepat). Akhirnya, kita memasukan pengetahuan tentang diri (variabel individu) yang berkaitan dengan komponen kognitif dan motivasi kinerja (Pengetahuan Diri).

\section{Pengetahuan Strategis}

Pintrich (2002) memaparkan pengetahuan strategi adalah pengetahuan pada strategi umum untuk belajar, berpikir, dan memecahkan masalah. Strategi ini dapat diterapkan pada semua atau sebagian besar disiplin ilmu atau domain materi pelajaran berbeda dengan strategi yang lebih spesifik dari disiplin atau domain. Pengetahuan strategi dapat digunakan di sejumlah besar tugas dan domain yang berbeda, lebih berguna untuk satu jenis tugas tertentu dalam satu mata pelajaran tertentu. Pengetahuan strategis meliputi pengetahuan tentang berbagai strategi yang mungkin digunakan oleh siswa untuk menghafal materi, untuk memperoleh makna dari bacaan dan untuk memahami apa yang mereka dengar di kelas atau apa yang mereka baca dalam buku-buku dan materi pelajaran lainnya.

Strategi-strategi metakognitif membantu siswa lebih efisien dan lebih memiliki kekuatan dalam belajar karena strategi metakognitif menolong siswa untuk menemukan informasi, menilai kapan siswa perlu tambahan sumber materi dan mengerti kapan harus menerapkan pendekatan yang berbeda terhadap suatu masalah yang ditemukan ketika siswa belajar (Hammond, Austin, Cheung dan Martin, 2003). Siswa yang 
semakin banyak belajar tentang strategi umum untuk belajar dalam konteks yang lebih khusus, mereka akan semakin mampu menggunakannya secara baik dalam berbagai bidang lain. Selanjutnya, siswa dapat memiliki pengetahuan tentang berbagai strategi metakognitif yang akan berguna bagi mereka dalam perencanaan, pemantauan, dan mengatur proses belajar dan berpikir.

Siswa yang tahu tentang berbagai jenis strategi untuk belajar, berpikir, dan memecahan masalah akan lebih cenderung akan menggunakan strategi tersebut dalam proses pembelajaran. Selanjutnya, jika siswa tidak mengetahui strategi untuk belajar, berpikir dan memecahkan masalah, dengan demikian mereka tidak bisa menggunakan strategi tersebut dalam belajar. Siswa yang tahu tentang strategi yang berbeda untuk tugas-tugas memori, misalnya lebih cenderung menggunakannya untuk mengingat kembali informasi yang relevan. Demikian pula, siswa yang tahu tentang strategi belajar yang berbeda lebih cenderung untuk menggunakannya ketika belajar. Anderson dan Krathwohl (2010), contoh-contoh pengetahuan stategis adalah sebagai berikut:

1. Pengetahuan bahwa mengulang-ulang informasi merupakan salah satu cara untuk mengingat informasi

2. Pengetahuan perihal beraneka strategi mnemonic untuk menghafal (misal menggunakan akronim untuk menghafal warna pelangi seperti mejikuhibiniu: merah, jingga, kuning, hijau, biru, nila, ungu)

3. Pengetahuan tentang berbagai strategi pengorganisasian seperti menuliskan garis besar dan menggambar diagram. Siswa dapat membuat proses metamorphosis kepompong menjadi kupu-kupu, supaya mudah dipahami untuk diri sendiri.

4. Pengetahuan untuk merencanakan strategi seperti merumuskan tujuan membaca, pengetahuan tentang strategi-strategi pemahaman-pemonitoran seperti menguji diri sendiri dan mengajukan pertanyaan pada diri sendiri. Setelah menerima materi dari guru di sekolah, kemudian di rumah siswa membaca ulang materi tersebut dan membuat catatan hal-hal apa saja yang sudah dipahami dan mencatat hal-hal yang belum dipahami untuk ditanyakan pada guru pada pertemuan selanjutnya.

5. Pengetahuan tentang analisis alat-tujuan seperti metode heuristik untuk menyelesaikan masalah pelik

6. Pengetahuan tentang masalah-masalah availability heuristic dan pengambilan sampel yang bias.

\section{Pengetahuan tentang Tugas-Tugas Kognitif}

Pengetahuan tentang tugas-tugas kognitif menjelaskan bahwa tugas belajar yang berbeda bisa dikatakan sulit, bisa juga dikatakan kurang sulit oleh siswa tertentu sesuai dengan kemampuan kognitif siswa dan situasi belajar. Hal ini bisa terjadi dikarenakan tugas yang berbeda memungkinkan memerlukan strategi kognitif yang berbeda pula. Sebagai contoh, sebuah tugas mengingat kembali lebih sulit daripada tugas mengenali sebuah suara, misalnya, karena dalam tugas mengingat kembali, individu harus secara aktif mencari memori dan mengambil informasi yang relevan, sedangkan dalam tugas mengenali suara, penekanannya adalah pada diskriminatif antara alternatif dan memilih jawaban yang tepat (Pintrich, 2002). Sebagai siswa yang mengembangkan pengetahuan mereka tentang belajar yang berbeda, strategi berpikir yang berbeda, pengetahuan ini mencerminkan "apa" dan "bagaimana" dari strategi yang berbeda. Paris, Lipson, \& Wixson (Pintrich, 2002) mengungkapkan bahwa siswa juga harus mengembangkan beberapa pengetahuan tentang "kapan"dan "mengapa" dari penggunaan strategi ini dengan tepat. Karena tidak semua strategi sesuai untuk semua situasi, siswa harus mengembangkan beberapa pengetahuan tentang kondisi yang berbeda dan tugas di mana strategi yang berbeda yang digunakan paling tepat.

Anderson dan Krathwohl (2010), contoh pengetahuan tentang tgas-tugas kognitif, yang meliputi pengetahuan kontekstual dan kondisional adalah sebagai berikut:

1. Pengetahuan bahwa tugas mengingat kembali (soal jawaban singkat), berbeda dengan tugas mengenali (soal pilihan ganda) yang pada 
umumnya lebih banyak menuntut kerja sistem memori. Siswa diberi tes tentang mata pelajaran sejarah, dalam tes tersebut soal dibagi menjadi dua bagian. Bagian pertama berupa pilihan ganda dan bagian kedua berupa essay, setelah dilakukan penilaian siswa tersebut memiliki skor yang rendah dalam jawaban pilihan ganda dan justru baik skor tinggi didapat pada jawaban essay.

2. Pengetahuan bahwa buku babon lebih sukar dipahami daripada buku teks atau buku popular

3. Pengetahuan bahwa tugas sederhana untuk menghafal hal-hal yang sederhana (misalnya mengingat no handphone teman) hanya memerlukan strategi pengulangan.

4. Pengetahuan bahwa strategi elaborasi seperti merangkum dan memparafrasakan dapat membuahkan pemahaman yang mendalam. Siswa di kelas meminta guru untuk kembali mengulang penjelasan mengenai satu kalimat tertentu yang belum bisa dipahami siswa. Atau, di dalam kelas siswa mencoba mengulang sendiri penjelasan guru sesuai dengan pemahamannya dengan maksud apabila siswa tersebut kurang tepat dalam memahami apa yang dijelaskan guru, guru bisa memberi penjelasan yang tepat.

5. Pengetahuan bahwa metode heuristic penyelesaian masalah sangat bermanfaat ketika siswa tidak mempunyai pengetahuan dalam bidang tertentu. Ketika siswa tidak mengetahui bagaimana terjadinya siang dan malam, siswa akan mencari tahu "apa" itu siang dan malam dan "bagaimana" siang dan malam bisa terjadi.

6. Pengetahuan tentang norma-norma sosial lokal dan umum, konvensional dan kultural untuk bagaimana, kapan dan mengapa menerapkan strategi tertentu. Siswa mampu menerapkan hal-hal yang dipelajari dari mata pelajaran Pendidikan Kewarganegaraan, seperti menghormati Negara dan para pahlawan yang telah gugur untuk kemerdekaan RI dengan memasang bendera di rumah saat menjelang HUT RI.

\section{Pengetahuan Diri}

Flavell (Pintrich, 2002) mengusulkan bahwa pengetahuan diri adalah komponen penting dalam pengetahuan metakognitif. Pengetahuan diri ini mencakup pengetahuan mengenai kekuatan dan kelemahan seseorang. Misalnya, seorang mahasiswa yang tahu bahwa dia lebih bisa mengerjakan tes berupa pilihan ganda dibanding tes berupa essay memiliki beberapa pengetahuan metakognitif tentang dirinya. Tidak sedikit siswa tidak mengetahui kalau sebenarnya dirinya tidak tahu sesuatu. Oleh karena itu pengetahuan diri berkaitan erat dengan kesadaran diri. Kesadaran diri yang luas dan mendalam dari pengetahuan dasar orang itu sendiri merupakan aspek penting dari pengetahuan diri. Akhirnya, individu perlu menyadari berbagai jenis strategi mereka cenderung mengandalkan dalam situasi yang berbeda. Sebuah kesadaran bahwa satu overrelies pada strategi tertentu ketika mungkin ada strategi yang lebih adaptif untuk tugas lainnya dapat menyebabkan kemungkinan perubahan penggunaan strategi.

Selain pengetahuan diri secara umum, individu juga memiliki keyakinan tentang motivasi mereka (Pintrich, 2002). Meskipun keyakinan motivasi biasanya tidak dipertimbangkan dalam model kognitif, ada bagian literature yang cukup banyak muncul menunjukkan hubungan penting antara keyakinan motivasi siswa, kognisi dan pembelajaran siswa (Pintrich \& Schrauben, 1992; Pintrich \& Schunk, 2002; salju, Corno, \& Jackson, 1996). Tampaknya penting bahwa sama seperti siswa perlu mengembangkan pengetahuan diri dan kesadaran diri tentang pengetahuan dan kognisi mereka, mereka juga perlu untuk mengembangkan pengetahuan diri dan kesadaran diri tentang motivasi mereka.

Dalam hal pembelajaran, pengetahuan diri bisa menjadi fasilitator penting namun bisa juga menjadi penghambat. Siswa yang mengetahui kekuatan dan kelemahan diri dapat menyesuaikan kognisi mereka sendiri dan berpikir untuk menjadi lebih bisa menyesuaikan dengan tugas yang beragam, dengan demikian mampu memfasilitasi pembelajaran. Jika, misalnya, seorang siswa menyadari bahwa dia tidak tahu banyak tentang 
topik tertentu, ia mungkin lebih memperhatikan topik tersebut saat membaca dan menggunakan strategi yang berbeda untuk memastikan dia mengerti mengenai topik yang sedang dipelajari. Dalam kebiasaan yang sama, jika siswa menyadari bahwa mereka mempunyai kesulitan dalam tes tertentu misalnya tes matematika vs tes sejarah, selanjutnya siswa tersebut dapat mempersiapkan diri dengan baik untuk tes matematika yang akan datang dengan kebiasaan belajar yang tepat. Siswa yang kurang mengetahui kelemahan dan kelebihan diri mereka sendiri kemungkinan akan kurang bisa beradaptasi pada situasi yang berbeda dan kurang bisa mengatur belajar mereka.

Anderson dan Krathwohl (2010), contoh pengetahuan diri adalah sebagai berikut:

1. Pengetahuan bahwa dirinya mempunyai pengetahuan yang mendalam pada sebagian bidang, tetapi tidak pada sebagian bidang lainnya. Seorang siswa yakin dan sadar bahwa apabila masuk jurusan Bahasa, suatu saat dia akan menjadi seseorang yang berhasil dibanding ketika masuk jurusan IPA karena siswa tersebut tidak pandai dalam bidang penghitungan yang rumit namun siswa tersebut selalu juara dalam lomba pidato dan baca puisi menggunakan bahasa Inggris dan bahasa Jepang.

2. Pengetahuan bahwa dirinya cenderung mengandalkan satu "alat kognitif" (strategi) dalam situasi tertentu. Seorang siswa yang belajar sejarah hanya dengan membaca dan menghafal peristiwa tertentu terjadi kapan, di mana dan siapa tokoh yang berperan penting, begitu pula dengan mata pelajaran matematika hanya menghafal rumus-rumus.

3. Pengetahuan yang akurat dan tidak palsu (kepercayaan diri yang berlebihan) tentang kemampuan sendiri untuk melakukan tugas tertentu.

4. Pengetahuan tentang tujuan-tujuan pribadi dalam melakukan suatu tugas. Seorang siswa belajar giat ketika kelas X supaya kelak bisa masuk kelas IPA dan bisa lulus dengan nilai yang baik untuk bisa kuliah di bidang kesehatan khususnya jurusan gizi.

5. Pengetahuan tentang minat pribadi dalam melakukan tugas tertentu. Siswa yang mengetahui bahwa dirinya tidak suka berhitung akan lebih mempersiapkan diri saat mengikuti pelajaran matematika dan mengerjakan PR bersama teman yang memang menyukai matematika.

6. Pengetahuan tentang keputusan pribadi tentang manfaat suatu tugas. Siswa berusaha keras dengan rajin mengikuti les tambahan dan menambah waktu belajar daripada bermain seperti biasanya supaya berhasil dalam ujian akhir semester.

\section{Manfaat Pengetahuan Metakognitif}

Pintrich (2002) mengungkapkan bahwa banyak siswa akan memperoleh pengetahuan metakognitifnya melalui pengalaman yang siswa dapatkan dimana dia belajar sesuatu. Setelah siswa dapat mengetahui pengetahuan metakognitifnya sendiri, para pendidik perlu tetap melakukan bimbingan dan pengamatan kepada siswa supaya bisa mengetahui tingkat pengetahuan metakognitif siswa. Menurut Pintrich (2002) guru dan siswa bisa memulai sebuah diskusi, guru menanyakan beberapa pertanyaan, mendengarkan jawaban dan berbicara dengan siswa. Melalui diskusi guru bisa secara cepat mengetahui kedalaman pengetahuan metakognitif siswa. Melalui ini pula guru dibantu untuk menyesuaikan metode pengajaran untuk membantu siswa memperoleh pengetahuan metakognitif. Guru juga sebaiknya membuka diri untuk menerima setiap siswa yang datang kepadanya untuk diskusi mengenai kesulitan dan hambatan yang dialaminya dalam proses belajar.

Akhirnya, ketika pengetahuan metakognitif telah dimiliki oleh siswa, hal tersebut akan menghasilkan sebuah proses pembelajaran yang berarti bagi siswa, tidak sekedar hanya berhenti sampai mengingat sebuah materi pelajaran saja. Hal tersebut berkaitan dengan pencapaian tujuan pendidikan. Tujuan-tujuan pendidikan yang menumbuhkan kemampuan untuk mengingat cukup mudah dirumuskan, tetapi tujuan-tujuan yang mengembangkan kemampuan untuk mentransfer lebih sulit dirumuskan, diajarkan dan dinilai. Siswa diharapkan dapat menggunakan 
kembali strategi belajar yang sama pada situasi dan masalah yang berbeda. Bransford mengungkapkan bahwa pengetahuan metakognitif pada semua strategi yang berbeda tampaknya berhubungan dengan transfer belajar, yaitu, kemampuan untuk menggunakan pengetahuan yang didapat dalam suatu situasi lain (Pintrich, 2002).

Ada tiga macam hasil belajar, ketiganya merupakan hasil suatu proses pembelajaran yang bisa terjadi kapan saja dan di mana saja. Mayer (2002), pertama adalah tidak ada aktivitas belajar (tidak ada aktivitas belajar yang diinginkan), kedua ialah belajar menghafal (rote learning), dan ketiga adalah belajar bermakna (meaningful learning). Dari ketiganya yang paling penting adalah belajar bermakna. Di sinilah peran pengetahuan Metakognitif memampukan siswa mencapai proses yang dinamakan belajar bermakna.

Belajar bermakna merupakan hal yang penting dan harapannya harus terjadi dalam setiap proses belajar. Mengapa? Kami memiliki sebuah ilustrasi seperti di bawah ini: "Di dalam kelas, Agnes membaca materi tentang rangkaian listrik menggunakan lampu, baterai dan kabel tembaga, ia membaca secara teliti dan berusaha memahaminya. Setelah membacanya Agnes mampu merangkai listrik tersebut di dalam kelas, dan berhasil membuat satu rangkaian. Setelah pulang ke rumah, malam harinya Agnes mencoba merangkai listrik dengan dua lampu dan menambah baterai. Dan ternyata percobaannya berhasil, Agnespun menyimpulkan ketika menambah lampu, rangkaian listrik memerlukan tambahan daya berupa baterai." Saat ini di Indonesia banyak siswa yang tidak bisa mentransfer informasi yang baru saja di dapatkan. Sehingga dalam menghadapi per-soalan baru dalam konteks yang baru seringkali siswa sudah kesulitan dan merasa "yang ini belum diajarkan oleh guru". Oleh karena itu, belajar bermakna menghadirkan pengetahuan dan proses-proses kognitif yang siswa butuhkan untuk menyelesaikan masalah. Penyelesaian masalah terjadi ketika siswa menggagas cara untuk mencapai tujuan yang belum pernah dia capai, yakni mengerti bagaimana cara mengubah keadaan jadi keadaan yang diinginkan (Mayer,2002).

\section{Belajar yang bermakna adalah mengkonstruk- sikan kerangka pengetahuan}

Fokus pembelajaran yang bermakna sesuai dengan pandangan bahwa belajar adalah mengkonstruksi pengetahuan di mana siswa memahami pengalaman-pengalaman mereka. Pembelajaran konstruktif mensyaratkan pembelajaran yang tidak sekedar menyampaikan pengetahuan faktual dan juga mensyaratkan pertanyaan-pertanyaan assesmen yang menuntut siswa bukan sekedar mengingat atau mengenali pengetahuan faktual. Proses kognitiflah yang menjadi alat untuk mendeskripsikan aktivitas-aktivitas kognitif siswa dalam pembelajaran konstruktif; proses-proses kognitif adalah cara-cara yang dipakai siswa secara aktif dalam proses mengkonstruksi makna.

\section{Proses Kognitif dalam Meretensi dan Mentransfer}

Kategori proses kognitif yang paling dekat dengan meretensi adalah Mengingat, sedangkan lima kategori lainnya merupakan proses-proses kognitif yang dipakai untuk mentransfer. Anderson dan Krathwol (2010) memaparkan ada 19 proses kognitif (Tabel B.5) yang sesuai dengan enam kategori proses kognitif. Sembilan belas proses kognitif ini saling terpisah satu sama lain dan menggambarkan keluasan dan batas-batas enam kategori proses kognitif.

Penulis beranggapan bahwa siswa dapat mengkonstruksikan kerangka pengetahuan dan mampu mentransfer pengetahuan apabila siswa sudah mampu "belajar bagaimana belajar" dan "berpikir mengenai berpikir" melalui pengetahuan tentang strategi belajar, pengetahuan tugas-tugas kognitif dan pengetahuan diri yang kesemuanya terdapat di dalam pengetahuan metakognitif.

\section{KESIMPULAN}

Kurikulum 2013 sudah mulai dilaksanakan dan pemerintah mengharapkan siswa mampu mengetahui cara belajar yang kreatif dan produktif. Belajar yang sesungguhnya terdapat dalam tujuan dari Kurikulum 2013 yaitu siswa dapat lebih baik dalam melakukan observasi, bertanya, bernalar, dan mengkomunikasikan 
(mempresentasikan), terhadap apa yang mereka peroleh atau mereka ketahui setelah menerima materi pembelajaran. Tujuan tersebut bisa dicapai apabila para pendidik dan peserta didik bisa mengetahui strategi, tugas-tugas kognitif peserta didik dan pengetahuan akan keadaan diri mereka sendiri. Tulisan ini menyajikan pengetahuan metakognitif sebagai dimensi pengetahuan yang penting yang sekiranya bisa dipertimbangkan sebagai dimensi yang perlu diketahui oleh para pendidik dan siswa. Pengetahuan metakognitif merupakan dimensi baru dari Taksonomi Revisi. Revisi dilakukan oleh Kratwohl dan Anderson, taksonomi menjadi dua dimensi yaitu dimensi kognitif dan dimensi pengetahuan. Dimensi proses kognitif terdiri dari: (1) mengingat (remember); (2) memahami (understand); (3) mengaplikasikan (apply); (4) menganalisis (analyze); (5) mengevaluasi (evaluate); dan (6) mencipta (create). Dimensi pengetahuan terdiri dari: 1) Faktual, 2) Konseptual, 3) Prosedural, dan 4) Metakognitif.

Pengetahuan metakognitif merupakan sebuah kategori yang baru dari pengetahuan Taxonomi yang telah di revisi. Bagaimanapun, pengetahuan metakognitif berperan penting dalam pembelajaran, ini merupakan sesuatu yang baru saja muncul dan banyak dibutuhkan. Pengetahuan Metakognitif memiliki komponen penting di dalamnya yaitu Pengetahuan strategi merujuk kepada pengetahuan strategi pada belajar dan berpikir. Pengetahuan akan tugas mereka dan konteks mereka menyajikan kembali pengetahuan tentang perbedaan macam-macam tugas kognitif seperti kelas dan aturan budaya. Terakhir, pengetahuan diri merupakan komponen penting dari pengetahuan metakognitif pada umumnya yang terdaftar secara pasti untuk pembelajaran siswa, secara eksplisit pengajaran pengetahuan metakognitif berguna untuk memfasilitasi perkembangan yang dibutuhkan. Sebagai hasil dari taxonomi revisi menekankan pada suatu kebutuhan untuk meluruskan tujuan, pengajaran, dan penilaian yang menghendaki kita untuk mempertimbangkan peran pengetahuan meta-kognitif di dalam tujuan pendidikan. Apabila peran metakognitif sudah ditingkatkan dalam diri siswa, siswa akan mampu menyusun strategi belajar untuk mencapai proses belajar yang bermakna.

\section{DAFTAR PUSTAKA}

Anderson, Lorin W \& David R. Krathwohl. 2010. Kerangka Landasan untuk Pembelajaran, Pengajaran dan Asesmen - Revisi Taksonomi Pendidikan Bloom. Yogyakarta: Pustaka Pelajar.

Fattah, Nanang. 2012. Analisis Kebijakan Pendidikan. Bandung: Rosdakarya

Hammond, Linda Darling, Kim Austin, Melissa Cheung \& Daisy Martin.2003. Thinking about Thinking: Metacognition. Stanford: Stanford University School of Education.

Holt, John. 2012. Bagaimana Siswa Belajar. Jakarta. Erlangga

Krathwohl, David R. 2002. A Revision of Bloom's Taxonomy: An Overview.Ohio: College of Education, The Ohio State University.

Mayer, Richard E. 2002. Rote Versus Meaningful Learning. Ohio: College of Education, The Ohio State University.

Pintrich, Paul R. 2002. The Role of Metacognitive Knowledge in Learning, Teaching, and Assessing. Ohio: College of Education, The Ohio State University.

Sindhunata. 2001. Pendidikan: Kegelisahan Sepanjang Zaman. Yogyakarta:Kanisius. 